magnesium concentrations may play a part in hyposecretion of parathyroid hormone, but our patient had consistently normal concentrations.

Stress, in the form of serious underlying illness, may contribute to the development of hypoparathyroidism; our patient had a complex medical history. In retrospect she was found to have had a low serum calcium concentration before her first admission to hospital and may have had subclinical hypoparathyroidism then. We recommend that the serum calcium concentration be checked promptly in any elderly patient after an unexplained convulsion.

We thank Dr B F Allam, consultant clinical biochemist at this hospital, for his invaluable help and guidance with this case.

Spinner MW, Blizzard RM, Childs B. Clinical and genetic heterogeneity in idiopathic Addison's disease and hypoparathyroidism. 7 Ciin Endocrinol 1968;28:795-804

${ }^{2}$ Graham K, Williams BO, Rose MJ. Idiopathic hypoparathyroidism: a cause of fits in the elderly. Br Med F 1979; $\mathrm{i}: 119-20$.

${ }^{3}$ Freedman DB, Shannon M, Dandona P, Prentice HG, Hoffbrand AV. Hypoparathyroidism and hypocalcaemia during treatment for acute leukaemia. Br Med f 1982;284:700-2.

+ Grieve RJ, Roberts H, Dixon PF, Hunter RD. Hypoparathyroidism and hypocalcaemia occurring during cancer chemotherapy. $\mathrm{Br} \mathrm{Med} \mathcal{F}$ $1982 ; 284: 1877$.

'Baker SL. Idiopathic hypoparathyroidism presenting as urinary and faecal incontinence. Br Med f $1982 ; 285$ :963-4.

(Accepted 14 February 1983)

Division of General Medicine, Unit A, Stobhill General Hospital, Glasgow G21 3UW

H K L SIMPSON, BSC, MRCP, registrar

C W HOWDEN, MB, MRCP, registrar

H L ELLIOTT, MB, MRCF, senior registrar

T J THOMSON, FRCP, consultant physician

Correspondence to: Dr C W Howden.

\section{Chlorpropamide-alcohol flushing and coronary heart disease in non-insulin dependent diabetics}

Chlorpropamide-alcohol flushing in non-insulin dependent diabetics ${ }^{i}$ and its relation te diabetic complications is a subject of much interest. and dispute. Barnett and Pyke ${ }^{2}$ and jerntorp and Almér ${ }^{3}$ suggested that non-insulin dependent diabetics with a positive chlorpropamidealcohol flushing test result have a diminished risk of large vessel disease. In the following study, however, we could not find any association between a positive reaction in the test and protection from coronary heart disease.

\section{Patients, methods, and results}

We examined 36 non-insulin dependent diabetics originally identified in 1979-81 in a study of $13:$ newly diagnosed diabetics aged 45-64 years who were representative of the diabetic population of Kuopio, Finland. In the original study population 23 diabetics had a history of myocardial infarction verified at hospital or electrocardiographic abnormalities diagnostic of previous myocardial infarction (Minnesota code $1 \cdot 1-1 \cdot 2$ ) and 21 diabetics were free of coronary heart disease by strict criteria (absence of chest pain by Rose cardiovascular questionnaire and normal electrocardiogram). These two groups of diabetics were invited to participate in this study and, finally, 20 diabetics with previous myocardial infarction (coronary heart disease group) and 16 diabetics free of coronary heart disease took part. The coronary heart disease group comprised nine men and 11 women, and the other group 10 mer: and six women. Of all 36 patients, 27 were being treated with diet, seven with sulphonylureas, and two with metformin.

The chlorpropamide-alcohol flushing test was performed in a room kept at a constant $20-22^{\circ} \mathrm{C}$. Patients were given $40 \mathrm{ml}$ of sherry 12 hours after $250 \mathrm{mg}$ of chlorpropamide. Temperature of the face was measured by a digital thermometer with a resolution of $0 \cdot 1^{\circ} \mathrm{C}$. Facial warmth, flushing, or burning of the face were regarded as subjective evidence of a positive reaction. An increase of over $1^{\circ} \mathrm{C}$ in skin temperature 30 minutes after the sherry was taken as objective evidence of a positive reaction.

Plasma insulir: concentration was determined by radioimmunoassay (Novo, Denmark) before and one and two hours after a $75 \mathrm{~g}$ oral glucose load. Serum tota! cholesterol and triglyceride concentrations were estimated by enzymatic methods. Serum high density lipoprotein cholesterol was determined from supernatant after precipitation by dextran sulphate and magnesium chloride. Serum chlorpropamide concentration was measured by high performance liquid chromatography. ${ }^{4}$ The $\chi^{2}$ test and Student's two tailed $t$ test were used for statistical analyses.

Of the 16 diabetics without coronary heart disease and the 20 with a history of heart disease, four and six, respectively, gave subjective evidence of flushing (difference not statistically significant). Objective evidence of flushing was obtained in six patients in each group (difference not significant). Use of other criteria for a rise in skin temperature (increase of $1.5^{\circ} \mathrm{C}$ or more 30 minutes after sherry or a maximal increase of $2^{\circ} \mathrm{C}$ or more, or both ; and a maxima temperature rise of over $1^{\circ} \mathrm{C}$ ) also showed no statistically significant difference in the prevalence of chlorpropamide-alcohol flushing between the groups,

Comparison of subjects with and without evidence of flushing showed no statistically significant differences in age, relative weight, serum concentrations of cholesterol, high density lipoprotein cholesterol, and triglycerides, plasma insulir concentration, or serum chlorpropamide concentration. The table summarises these results. In the coronary heart disease group flushers had lower high density lipoprotein cholestero: concentrations than had the non-flushers $(p<0.005)$.

\section{Comment}

Our results dic not confirm reports ${ }^{2}$ of an association between chlorpropamide-alcohol flushing and a diminished risk of large vessel disease. Contradictory results may be explained by differences in the selection and treatment of diabetics, by differences in the definition of large vessel complications studied, and by different criteria used to define a positive reaction in the chlorpropamidealcohol flushing test

The test was carried out in two groups of non-insulir dependent diabetics who had been included on a larger population based survey. The presence o: absence of coronary heart disease was determined by strict criteria. None of the diabetics was receiving chlorpropamide as maintenance treatment. Long term chlorpropamide increases the proportion of patients giving positive reactions in the test ${ }^{5}$ and is thus a confounding factor in studies correlating chlorpropamidealcohol flushing with small vessel or large vessel complications.

Our results do not support the view that non-insulin dependent diabetics giving positive reactions in the chlorpropamide-alcohol flushing test have a diminished risk of large vesse! disease.

A grant from Orion Corporation Research Foundation is gratefully acknowledged.

Relative weight, concentrations of high density lipoprotein cholesteroi, plasma insulin values during orai glucose tolerance test, and serum chlorpropamide concentrations in flusher and non-flusher diabetics without and with coronary heart disease. Values are means $+S E M$

\begin{tabular}{|c|c|c|c|c|c|c|}
\hline & \multirow{2}{*}{$\begin{array}{c}\text { Relative } \\
\text { weight }(" .,)\end{array}$} & \multirow{2}{*}{$\begin{array}{l}\text { High density } \\
\text { lipoprotein } \\
\text { cholesterol } \\
(\mathrm{mmol} / \mathrm{l})\end{array}$} & \multicolumn{3}{|c|}{ Plasma insulin after oral glucose $(\mathrm{mU} / \mathrm{l})$} & \multirow{2}{*}{$\underset{\substack{\text { Serum } \\
\text { chlop/l) }}}{\text { (mglde }}$} \\
\hline & & & $\mathrm{Oh}$ & $1 \mathrm{~h}$ & $2 \mathrm{~h}$ & \\
\hline \multicolumn{7}{|c|}{ Diabetics without coronary heart disease } \\
\hline $\begin{array}{l}\text { Non-flushers }(n=10) \\
\text { Flushers }(n=6)\end{array}$ & $\begin{array}{l}133 \cdot 8: 9 \cdot 6 \\
139 \cdot 0+11 \cdot 6\end{array}$ & $\begin{array}{l}1 \cdot 17: 0.08 \\
1.17: 0 \cdot 18\end{array}$ & $\begin{array}{l}23 \cdot 1+6 \cdot 8 \\
18 \cdot 8+7 \cdot 6\end{array}$ & $\begin{array}{l}58 \cdot 8+16 \cdot 4 \\
50 \cdot 3 \cdot 21 \cdot 6\end{array}$ & $\begin{array}{l}61 \cdot 0+13 \cdot 9 \\
44 \cdot 3+19 \cdot 0\end{array}$ & $\begin{array}{l}25 \cdot 5+1 \cdot 8 \\
21 \cdot 9+2 \cdot 1\end{array}$ \\
\hline \multicolumn{7}{|c|}{ Diabetics with coronary heart disease } \\
\hline $\begin{array}{l}\text { Non-flushers }(n=14) \\
\text { Flushers }(n=-6)\end{array}$ & $\begin{array}{l}145 \cdot 2+7 \cdot 7 \\
128 \cdot 8 \div 5 \cdot 6\end{array}$ & $\begin{array}{l}1.07+0.08 \\
0.76=0.06\end{array}$ & $\begin{array}{l}28 \cdot 8 \div 3 \cdot 7 \\
30 \cdot 5: 5 \cdot 7\end{array}$ & $\begin{array}{l}65 \cdot 6+10 \cdot 4 \\
64 \cdot 5+9 \cdot 2\end{array}$ & $\begin{array}{l}65 \cdot 1 \pm 10 \cdot 4 \\
58 \cdot 5 \pm 10 \cdot 1\end{array}$ & $\begin{array}{l}23 \cdot 8 \pm 0 \cdot 8 \\
22 \cdot 2 \pm 1 \cdot 6\end{array}$ \\
\hline \multicolumn{7}{|c|}{ All diabetics } \\
\hline $\begin{array}{l}\text { Non-flushers }(n=24) \\
\text { Flushers }(n=12)\end{array}$ & $\begin{array}{l}140.5: 6.1 \\
133 \cdot 9 \div 6.6\end{array}$ & $\begin{array}{l}1 \cdot 11=0.05 \\
0.96 \pm 0 \cdot 11\end{array}$ & $\begin{array}{l}26 \cdot 4 \div 3 \cdot 6 \\
24 \cdot 7 \div 5 \cdot 1\end{array}$ & $\begin{array}{l:l}62.8 & 9.3 \\
57.4 & 11.9\end{array}$ & $\begin{array}{l}63 \cdot 4+8 \cdot 4 \\
51 \cdot 9: 10 \cdot 9\end{array}$ & $\begin{array}{l}24 \cdot 5: 0.9 \\
22 \cdot 1 \pm 1 \cdot 3\end{array}$ \\
\hline
\end{tabular}

Conversion: SI to traditional units-High density lipoprotein cholesterol: $1 \mathrm{mmol} / 1 \approx 38.6 \mathrm{mg} / 100 \mathrm{ml}$. 
' Pyke DA, Leslie RDG. Chlorpropamide-alcohol flushing: a definition of its relation to non-insulin-dependent diabetes. $B r$ Med $\mathcal{F} 1978$;ii : 1521-2.

? Barnett AH, Pyke DA. Chlorpropamide-alcohol flushing and large-vessel disease in non-insulin-dependent diabetes. $\mathrm{Br}$ Med F 1980;281:261-2.

${ }^{3}$ Jerntorp P, Almér L-O. Chlorpropamide-alcohol flushing in relation to macroangiopathy and peripheral neuropathy in non-insulin dependent diabetes. Acta Med Scand 1981;suppl 656:33-6.

- Hill RE, Creciolo J. Determination of serum tolbutamide and chlorpropamide by high-performance liquid chromatography. $\mathcal{F}$ Chromatogr $1978 ; 145: 165-8$

${ }^{5}$ Jerntorp P, Almér L-O, Melander A. Is the blood chlorpropamide concentration critical in chlorpropamide-alcohol flush? Lancet $1981 ; \mathrm{i}$ : $165-6$

(Accepted 14 February 1983)

Department of Medicine, University Central Hospital of Kuopio, Kuopio, Finland

M LAAKSO, MD, assistant physician

K NUORVA, medical studen

A ARO, MD, associate chief

$M$ UUSITUPA, $M D$, lecturer in medicine

O SIITONEN, MD, lecturer in medicine

Department of Pharmacology, University of Turku, Finland

R HUUPPONEN, MD, research assistant

Correspondence to: Dr Markku Laakso, Department of Medicine, University Central Hospital of Kuopio, 70210 Kuopio 21, Finland.

\section{Bronchoconstriction in response to ipratropium bromide}

Ipratropium bromide is a new anticholinergic compound that is used increasingly to treat patients with limited airflow obstruction. Paradoxically, however, it may cause bronchoconstriction in occasional patients with atopic asthma. ${ }^{1}$ It has been suggested that this bronchoconstrictor response may result from increased viscosity of sputum in the airways ${ }^{1}$ or perhaps from altered bronchial reactivity to anticholinergic drugs in these patients. ${ }^{2}$ We report on a patient with extrinsic bronchial asthma who responded adversely to inhaled ipratropium bromide. We challenged the patient with two concentrations of ipratropium bromide and compared the effects with those of inhaled isotonic saline, atropine methonitrate, and sodium bromide solution to investigate the mechanism concerned.

\section{Case report}

While participating in a pharmacological study a 34 year old woman with atopic asthma and eczema developed pronounced and prolonged bronchoconstriction after inhalation of ipratropium bromide nebuliser solution ( $1 \mathrm{~g} / \mathrm{l}$ isotonic saline) given through a Wright nebuliser. Her asthma was well controlled with sodium cromoglycate $20 \mathrm{mg}$ four times a day, and she used salbutamol aerosol $200 \mu \mathrm{g}$ as required for symptomatic relief. All her drugs had been stopped 12 hours previously.

She was asked to attend on five afternoons after having stopped her drugs for at least 12 hours. Forced expiratory volume in one second was recorded with a water sealed spirometer (Godart Pulmotest). After a stable baseline reading had been obtained she was made to inhale ipratropium bromide $(0.25 \mathrm{~g} / 1$ or $1 \mathrm{~g} / \mathrm{l})$, atropine methonitrate $(10 \mathrm{~g} / \mathrm{l})$, sodium bromide $(0 \cdot 25 \mathrm{~g} / \mathrm{l})$, or isotonic saline through a Wright nebuliser at tidal breathing for five minutes. Ipratropium bromide, atropine, and sodium bromide were all dissolved in isotonic saline, and treatments were carried out in a single blind fashion. Forced expiratory volume in one second was recorded at one, three, four, seven, 10, 15, 20, 25, and 30 minutes after inhalations. She developed severe bronchoconstriction after inhaling ipratropium bromide (at both concentrations) and sodium bromide; isotonic saline did not cause any change from the baseline value of forced expiratory volume in one second (figure). Bronchodilatation occurred after inhalation of atropine methonitrate, $\stackrel{\text { w }}{\sim}$ the maximal increase in forced expiratory volume in one second being $33 \%$ at 20 minutes; this increase was still present at 30 minutes.

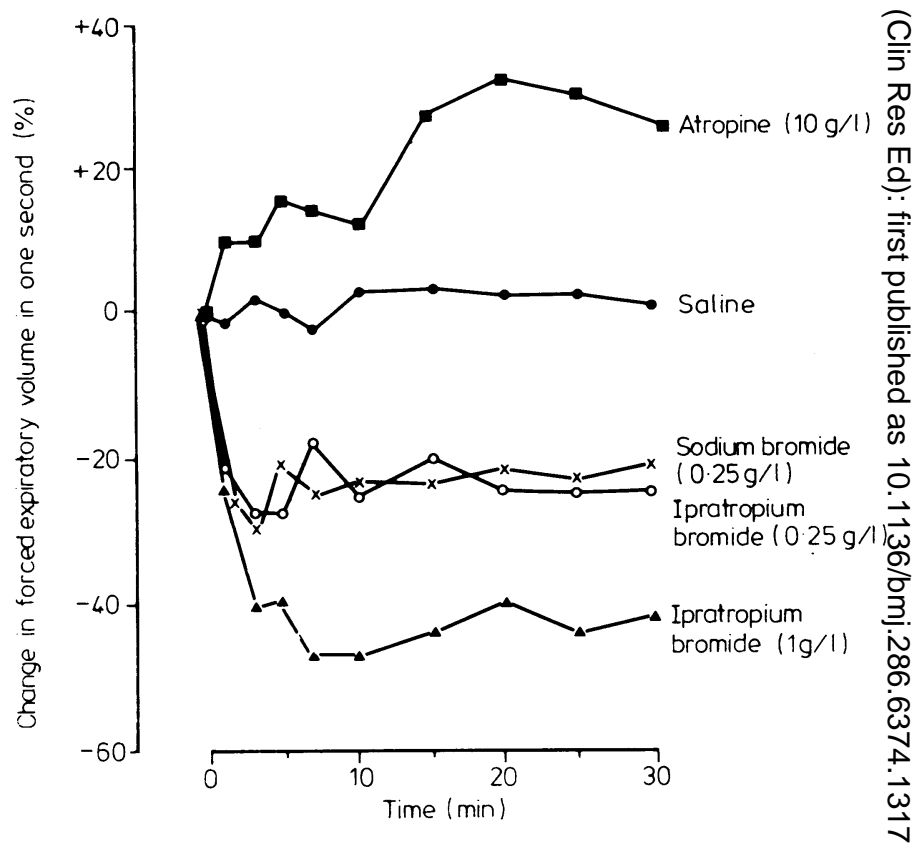

Percentage change in forced expiratory volume in one second after inhalationo of ipratropium bromide, atropine methonitrate, sodium bromide, and saline.

\section{Comment}

This patient developed bronchoconstriction within a minute afterc inhaling ipratropium bromide, with an appreciable fall in the forced $\square$ expiratory volume in one second. A similar response was observedo after challenge with sodium bromide solution. In contrast, she showed bronchodilatation after inhaling atropine methonitrate. The broncho- $\overline{0}$ constrictor response to ipratropium bromide was unlikely to haveڤ been due to changes in sputum viscosity or an altered bronchial ${ }^{\mathbb{Q}}$ reactivity to inhaled anticholinergic drugs as she did not show a $\Rightarrow$ similar response to atropine. Furthermore, the drugs were dissolved in isotonic saline to avoid airways responses induced by hypotonic and hypertonic solutions. ${ }^{3}$ The bronchoconstriction was most probably related to an adverse reaction to bromide. It is difficult, however, to postulate whether bromide acts directly on the bronchial smooth muscle or the vagal receptors or causes non-specific degranulation of mast cells.

We thank Mrs Rita Jack for technical help.

1 Connolly CK. Adverse reaction to ipratropium bromide. Br Med $\mathcal{F} 1982 ;$

$285: 934-5$.
2 Jolobe OMP. Adverse reaction to ipratropium bromide. $\mathrm{Br} \mathrm{Med} \mathcal{F} 1982 ;$; 285: 1425-6.

${ }^{3}$ Schoeffel RE, Anderson SD, Altounyan RE. Bronchial reactivity in response to inhalation of ultrasonically nebulised solutions of distilledo water and saline. $\mathrm{Br}$ Med $\mathcal{f} 1981 ; 283$ :1285-7.

(Accepted 14 February 1983)

Department of Respiratory Medicine, Western Infirmary, Glasgow G11 6NT

K R PATEL, PHD, FRCP, consultant physician

W M TULLETT, MB, MRCP, medical registrar

Correspondence to: Dr K R Patel. 